\title{
In Between the System And the Margins: Community Organizations, MANDATORY CHARGING AND IMMIGRANT VICTIMS OF ABUSE
}

\author{
RASHMEE SingH
}

\begin{abstract}
The literature on mandatory charging and prosecution policies consistently finds that zero tolerance approaches to woman abuse often harm, rather than help, abused immigrant women. The unexpected removal of abusers triggers detrimental consequences if women are dependent on their partners for immigration status, financial assistance, and linguistic support. The violence that immigrant women experience at the hands of the police and courts has led to repeated calls to shift the responsibility of women abuse from the criminal justice system to the community. However, accessing community supports may not be so straightforward either. For a variety of reasons, many abused immigrant women find silence less risky than disclosing abuse. These dilemmas highlight the importance of acquiring more insight into the mediating role that community organizations perform between the criminal justice system and immigrant communities. Accordingly, the following exploratory study offers a glimpse into the antiviolence work of immigrant community organizations in Toronto, Ontario.

Key Words: woman abuse; immigrant women; criminal justice system; immigrant community organizations
\end{abstract}

Résumé. La littérature sur les politiques liées aux poursuites et à l'inculpation obligatoire conclue uniformément que la politique de tolérance zéro en ce qui a trait à l'abus des femmes a souvent tendance à nuire plutôt qu'aider les femmes immigrantes abusées. Le retrait inattendu des abuseurs représente un élément déclencheur entraînant des conséquences nuisibles lorsque les femmes sont dépendantes sur leur partenaire pour obtenir le statut d'immigrant, de l'assistance financière et du support linguistique. La violence que subissent les femmes immigrantes aux mains de la police et des cours a entraîné plusieurs individus à revendiquer un déplacement de la responsabilité pour l'abus des femmes du système de justice criminelle vers la communauté. Néanmoins, accéder aux services communautaires n'est pas nécessairement plus simple. Pour toutes sortes de raisons, plusieurs femmes immigrantes abusées concluent que demeurer si- 
lencieuse est moins dangereux que de divulguer l'abus qu'elles subissent. Ces dilemmes soulignent l'importance de comprendre davantage le rôle médiateur que jouent les organismes communautaires entre le système de justice criminelle et les communautés immigrantes. Ainsi, ce travail de recherche exploratoire offre un aperçut du travail de la lutte contre la violence entrepris par les organismes communautaires immigrants à Toronto, en Ontario.

Mots clés: l'abus des femmes; femmes immigrantes; système de justice criminelle; organismes communautaires immigrants

\section{INTRODUCTION}

he deficiencies of current criminal justice responses to woman abuse have triggered repeated calls to augment community-based services for victims, particularly abused immigrant ${ }^{1}$ women (Stark 2005: Mills 2003). ${ }^{2}$ In contrast to early lobbying efforts, which focused on mandating criminal justice intervention, emphasis is now on community-based supports, due to mounting evidence suggesting that immigrant victims are disproportionately harmed, rather than helped, by "aggressive" policing and prosecution. ${ }^{3}$ Unfortunately, accessing assistance from nonprofit organizations may not be straightforward either. In many immigrant communities, ${ }^{4}$ keeping quiet rather than publicly acknowledging gendered violence is often preferred, largely in response to the pressures associated with managing widely held racist and xenophobic percep-

1. The term "immigrant" has multiple meanings. For the purpose of this discussion, I employ it as both a legal status and an ethnic marker. As a legal category, the term describes those individuals who have moved to Canada from other parts of the world and who may or may not have legal status in Canada. As an ethnic marker, it is used to refer to racialized diasporic populations.

2. Mills (2003) recommends decentring the criminal justice system entirely and replacing formal legal intervention with community-based services and Intimate Abuse Circles (IACs), a restorative justice approach. Stark (2005) reviews various critiques of the mandatory charge policy, focusing in particular on a report entitled "Safety and Justice for All." The following is his summary of its recommendations: "The movement should gradually 'divest' from the partnership with criminal justice ... replace 'mandatory' arrest with victim discretion, restore the emphasis on 'community-based' interventions, reshape efforts to meet the needs of poor and minority victims primarily, and forge alliances with progressive constituencies that have been alienated by the partnership with "law and order"' (Stark 2005:153). While Stark is a proponent of augmenting community-based supports, in contrast to Mills (2003), he is not a proponent of employing them in lieu of criminal justice interventions.

3. Since the 1980s, cases of woman abuse have been subject to mandatory charging throughout Canada. Also known as zero tolerance or "aggressive" intervention, it was assumed that mandating police and court intervention and pursuing charges regardless of victim preference would ensure the safety of abused women.

4. The term "community" here refers to immigrant men and women. 
tions that woman abuse ${ }^{5}$ is an immigrant or minority problem (Crenshaw 1991:1256). ${ }^{6}$ Immigrant victims also indicate that such "culturalized" explanations of violence perpetuate images of the oppressed, non-Western woman - a myth they are reluctant to feed into - which reinforces their silence (Thorncliffe Neighbourhood Office 2006; MacLeod and Shin 1990; Smith 2004). Immigrant victims thus often have to make difficult decisions about disclosing violence; while they undoubtedly want the abuse to stop, the potential of jeopardizing the integrity of their communities or inciting stereotypes imposes several barriers to coming forward and seeking assistance (Menjivar and Salcido 2002; Shirwadkar 2004; Crenshaw 1991; Smith 2004:28). ${ }^{\text {? }}$

These dilemmas raise several questions about what specifically occurs on the frontlines of community-based, antiviolence agencies working with immigrant women. ${ }^{8}$ If immigrant victims are indeed hesitant to seek help from the police, courts, and their communities, and if they are more likely to view silence as less risky than disclosing violence, how do women find their way to community-based supports in the first place? In addition, in cases where mandatory charging and prosecution have

5. Razack has written extensively on "culture talk" and the myths and narratives in white settler societies that attribute violence against women in racialized immigrant populations to "culture" (Razack 1998). This discursive construction is commonplace in both academic literature and media accounts of racialized gendered violence (Jiwani 2006). Explanations that emphasize cultural factors at the expense of structural forces both stigmatize and pathologize immigrant communities, enabling their construction as the barbaric "other."

6. It is important to note that barriers to public discussions of woman abuse exist in all contexts, not only in immigrant communities. For the purpose of this discussion, this paper will only comment on the immigrant-specific factors that contribute to the silencing of violence against women and the impact of this silencing on the service delivery of community-based service providers.

7. As Crenshaw (1991) points out in her discussion of violence against women and antiracist politics: "People of color often must weigh their interests in avoiding issues that might reinforce distorted public perceptions against the need to acknowledge and address intercommunity problems" (Crenshaw 1991:1256).

8. In discussing the experiences of immigrant women in general terms, it is not my intention to obscure the distinctions amongst immigrant women or homogenize their experiences of violence, the criminal justice system, and community organizations: class and ethno-racial differences are just a few of the multitude of factors that distinguish their experiences. The focus on group rather than on individual experience is in part a continuation of the inquiry into the social and economic conditions unique to the process of immigrating that complicate criminal justice and community-based interventions to woman abuse. Tenuous legal status, limited fluency in English, and the emphasis on Canadian credentials and work experience are some of the obstacles that exacerbate the vulnerability of abused immigrant women. Whereas not all individual immigrant victims encounter these specific barriers, these obstacles are, for the most part, unique to the immigration experience in general. This study is concerned with how these factors complicate the abilities of community-based service providers to effectively respond to immigrant victims of woman abuse. 
already been invoked, what are community-based organizations able to do to disentangle women from the criminal justice system? Finally, what does the mediating work of community-based, antiviolence activists entail? Surprisingly, despite the growing interest in their potential to ameliorate the marginalization of abused immigrant women following police and court intervention, very little is known about the work of community agencies and the details of their interactions with the people they serve.

In an attempt to offer some preliminary insight into the field, this study will report on the findings of exploratory research conducted with community-based service providers at legal clinics, settlement organizations, and immigrant women's organizations in Toronto between 20062008. The project draws primarily on interview findings with service providers, as well as insights acquired from ethnographic observation of a day-long workshop on immigrant and refugee victims of woman abuse held in Toronto in February of 2008. The workshop focused on developing best practices when intervening in cases of woman abuse in immigrant communities and brought together over twenty service providers who routinely work with abused immigrant women throughout the greater Toronto area. Informal discussions with front-line staff, executive directors, and community organizers were conducted during the workshop and incorporated into the study. Finally, this paper is also informed by my own professional experiences working in the criminal justice system as a front line support worker for victims of woman abuse, and in the nonprofit sector as a comanager of several immigrant and women's organizations in Toronto between the years of 2000-2004. The central objective of this study is a richer understanding of how agencies advise and support abused immigrant women, particularly in light of the state violence victims often endure as a consequence of mandated criminal justice intervention. Another goal is to gain insight into how service providers overcome or negotiate the silence surrounding gendered violence.

The study is part of a larger theoretical project on immigrant community organizations in Toronto and the mediating work they perform between the criminal justice system and civic society. I consider the project "exploratory" given that the findings on which it is based comprise only a segment of the data generated in the wider study. It is, therefore, not a large scale, sociological analysis of a representative sample of immigrant community organizations in Toronto. The research findings are thus not generalizable, and the sample size is not large enough to draw conclusions regarding best practices for all immigrant service organizations in Toronto. However, the data offer rich detail and preliminary insight into issues that have so far been neglected in the literature 
critiquing mandatory charging and aggressive prosecution practices, in research on immigrant victims of abuse, and in existing feminist debates on using the law to end violence against women.

In order to fully understand the context in which community organizations perform their work, some background on mandatory criminal justice interventions and their impact on abused immigrant women is necessary, since systemic practices often dictate the realm of potential strategies for service providers working in the nonprofit sector. The theoretical debates these policies have generated within feminism will also be reviewed. The next section will provide a very brief review of mandatory criminal justice intervention and the steps that led to its incorporation. A discussion of the immigrant specific factors that exacerbate the vulnerability of abused immigrant women in the wake of aggressive policing and prosecution will follow.

\section{“Just like any other Crime": The Emergence of Mandatory Criminal Justice Interventions in CaSes of Woman Abuse}

The "no drop" policy is just one example of an array of legal interventions in recent years to counter violence against women, the roots of which date back to the advent of the women's movement in the 1970's. Though many feminists expressed vehement opposition to embracing criminalization as a strategy, liberal feminist agendas that called for the police and courts to treat violence against women "just like any other crime" achieved the most currency. ${ }^{9}$ Although they were critical of the police and courts, liberal feminists believed that legal reform and intervention was both possible and essential to sending out the message that violence against women was wrong and intolerable. The impetus for their get-tough approach stemmed from several factors, the most important being a history of systemic neglect. Though laws prohibiting violence against wives had been in effect since 1909, they were rarely invoked. Police and prosecutors generally viewed woman abuse as a family, and therefore private, matter that was best addressed outside the realm of the criminal law. Consequently, when investigating, the police generally responded as social workers, engaging in mediation rather than laying charges (Martin and Mosher 1995).

The known dynamics of abusive relationships, particularly the pressures victims experience from their abusive partners to drop charges also

9. Some also question whether or not feminist advocacy was indeed the driving force behind mandatory criminal justice intervention. Hilton (1988), for example, argues that the eventual incorporation of zero tolerance strategies arose from the government's appropriation of feminist discourse (see Hilton 1988). 
figured prominently in the liberal feminist rationale to implement nodrop policies. Activist Linda MacLeod emphasized this concern in Wife Battering in Canada: The Vicious Circle, one of the earliest and most influential reports to recommend mandated criminal justice intervention. According to MacLeod,

by allowing the wife to be persuaded by her husband to withdraw her complaint, the legal system again is giving official recognition to the powerlessness of the woman in the home and to the acceptance of wife battering as a private matter. (MacLeod 1980:43)

Though she does not explicitly advocate a mandatory charge and prosecution policy, the arguments presented in Wife Battering in Canada were central to the formation of an all-party, Parliamentary standing committee, which in turn led to the eventual incorporation of a zero tolerance approach.

Another key player in the fight to mandate police response was the London Ontario Coordinating Committee on Family Violence (LCCFV) (Hilton 1988). After finding that police divisions in London laid charges in less than 3 percent of woman abuse cases, the committee recommended the removal of police discretion and a uniform policy of arrest. Accordingly, the London Police Department became the first to implement mandatory charging in May of 1981 (Department of Justice 2005). The federal government soon followed. On July 15, 1982, the Solicitor General of Canada endorsed the strategy and directed the Canadian Association of Chiefs of Police to comply with this directive. By 1986, Attorneys General and Solicitors General initiated efforts to standardize aggressive police and prosecutorial practices across Canada through a series of federal directives instructing the police to lay charges "where an investigation reveals reasonable and probable grounds to believe a serious indictable offence has been committed as part of a domestic dispute" (Department of Justice 2005).

Currently, all jurisdictions in Canada employ mandatory charging and prosecution in cases of woman abuse (Department of Justice 2005). Ontario's directive as stated in the province's Policing Standards Manual, notes the following: "the procedures should provide that in all domestic violence occurrences an officer is to lay a charge where there are reasonable grounds to do so"(Ministry of the Solicitor General 2000: Guideline 15,7$)$. The policy clarifies further, "a decision to lay charges should not be influenced by any of the following factors," including, amongst others, "the victim's unwillingness to attend court proceedings or the officer's belief that the victim will not cooperate," as well as "the officer's concern about reprisals against the victim by the suspect" (Min- 
istry of the Solicitor General 2000: Guideline 16c; 16g, 7). ${ }^{10}$ Along with the expectation that a mandatory charge policy will clearly convey that violence against women is an intolerable criminal offence, the primary objectives of this strategy are: to relieve victims of the responsibility to lay charges; to increase and encourage the reporting of woman abuse incidents; to reduce recidivism; and to ensure a punitive response to woman abuse (Department of Justice 2005:11). The directive provides similar justifications for overlooking victim preferences during the prosecution process. By preventing victims from dropping charges, thereby forcing them to testify, mandated systemic intervention assumes that victims will be better protected and the prospects of recidivism reduced.

\section{“Women as a Whole?”: Feminist Debates on Mandatory Charging}

The mandatory charge policy encapsulates several of the theoretical and substantive issues addressed in wider feminist debates on whether or not the police and courts should be enlisted as partners in the struggle to end violence against women (Snider 1994; Smart 1989). Since the beginning of the women's movement, feminists have differed over the transformative potential of the state and the law, particularly in relation to criminalization strategies. While some argue that tougher laws and stiffer sentences are essential to preventing male violence, others caution against such strategies, noting the role of the criminal justice system in perpetuating racism, sexism, classism, and related systems of oppression (Morrow et al. 2004; Martin and Mosher 1995). Many also question the retribution model and point out the inherent contradictions between feminist goals of empowerment and embracing "injury obsessed agendas" (Snider 1994; Martin 1998). The mandatory charge policy was just one of many antiviolence strategies to stir divisions between those who questioned relying on the criminal justice system, and those who insisted preventing male violence could only be achieved through ensuring the policing, prosecution, and punishment of offenders.

Some of the more specific feminist debates around mandatory charging and prosecution revolve around the issue of removing victim choice

10. Police mandates throughout Canada are similar to Ontario's approach, with some variations. In Quebec, the decision to charge rests with the crown attorney. Similarly, in New Brunswick, the police only lay charges upon securing the approval of crown attorneys (Department of Justice 2005:11). In British Columbia, although the Crown Spousal Assault policy is currently under review, the revised policy will continue to emphasize that the "decision to charge or continue to prosecute should not be determined by the victim's wishes" (British Columbia Ministry of Attorney General 2004). British Columbia also allows for precharge diversion measures in exceptional cases, with the consent of a crown attorney. A similar program exists in the Northwest Territories (Department of Justice 2005:12). 
and the potential of disempowering women. Advocates acknowledge that pursuing charges whether or not victims are on side is controversial and contradictory to feminist goals of empowerment; however, they claim that suspending victim choice is a necessary evil, crucial to ensuring the safety of individual victims, as well as "women as a whole" (Hanna 1996). Their arguments emerge from several assumptions about the societal impact of criminal justice intervention and victim safety. In relation to individual victims, proponents claim that women in abusive situations may be incapable of making "independent and informed decisions about arrest," due to isolation, fear, and the imbalance of power in abusive relationships (Wanless 1996:548). Their second point, that the policy benefits not just individual victims, but all women, centres on the assumption that guaranteed legal intervention transforms patriarchal norms, thereby alleviating the social and cultural supports that lead to violence against women in the first place.

Those who question this approach, however, argue that mandatory criminal justice intervention does little to disturb the root causes of male violence. Though criminalization has managed to shift woman abuse from a private to public matter, the emphasis on the punishment of individual offenders means that responsibility for the crime still rests at the level of individual men rather than society as a whole (Martin and Mosher 1995). Critics also challenge the idea that mandatory arrest benefits all women, questioning in particular the construct of "women's interest" and its essentialist foundations (Martin and Mosher 1995). Strategies to counter woman abuse, they argue, must acknowledge how race, class, citizenship, and other structural locations intersect with gender, and complicate a woman's experience of violence as well as her interaction with the criminal justice system. Whether women are harmed or helped by the police and courts is largely contingent on their social positioning as white or racialized, citizens or immigrants, middle-class or poor. The specific harms that immigrant women endure, or could potentially endure following mandated criminal justice intervention illustrate the essentialist flaws of the "women as a whole" argument well.

\section{The Impact of Mandated Criminal Justice Intervention on IMMIGRANT WOMEN}

Although laced with good intentions, proponents of mandatory charging did not anticipate the potentially detrimental effects of conflating victim safety with the removal of victim choice, and of assuming that all victims view the police as protectors. The few available studies that 
explore the impact of aggressive criminal justice interventions uncover the multitude of immigrant specific factors that exacerbate the structural vulnerability of abused women: precarious immigration status, financial and linguistic dependency, employment barriers, isolation, and fears of being ostracized by their communities have all been flagged as concerns (Wachholz and Miedema 2000; Martin and Mosher 1995; Mosher 2005). Wachholz and Miedema (2000), for instance, found that over half of the 48 women in their study reported that police intervention would "isolate them from friends and community, foster feelings of disempowerment and place them in positions where they are forced to interact with someone who they may not trust, but who has power over them" (Wachholz and Miedema 2000:308). ${ }^{11}$ Many abused immigrant women also report that they have no one else to rely on in the event that their partners are arrested and removed from the home. Without extended networks of family and community supports, most felt extremely isolated when partners were arrested (Wachholz and Miedema 2000).

The potential loss of economic and linguistic supports is another serious consequence of mandatory criminal justice intervention. Martin and Mosher (1995) $)^{12}$ and Wachholz and Miedema (2000) found that in instances where women rely on their abusers for these forms of support, mandatory charging may cause more harm than good..$^{13}$ The sudden loss of financial support following the unexpected removal of abusers from homes leaves many women unprepared for managing households, rent, and mortgages on their own. Although many economically disadvantaged, Canadian-born victims of abuse may also share this fate, the consequences for immigrant women are far worse, given the barriers they encounter in the labour market or when attempting to access social assistance (see Mosher 2005). ${ }^{14}$ The employment difficulties endured by

11. Wachholz and Miedema (2000) conducted interviews and focus groups with 48 women living in New Brunswick in 1997 to acquire their views on mandatory charging. The participants in their study had immigrated to Canada from a number of regions, including South Asia, Africa, the Middle East, and Europe. The socioeconomic status of the women in the study was also diverse: reported family incomes ranged from $\$ 20,000$ to over \$100,000 (Wachholz and Miedema 2000:307).

12. Martin and Mosher (1995) conducted interviews with eleven immigrant women in Toronto, Ontario. The majority of participants in the sample had few marketable employment skills and little job experience or formal education. All but one woman had limited fluency in English (Martin and Mosher 1995:20).

13. My own professional experiences as victim support worker in the provincial courts in Toronto corroborate these research findings. A number of recent immigrant victims that I had seen were completely dependent on their partners both economically and linguistically. Following the arrest of partners, few were aware of how to access social services or if they were even eligible for support.

14. According to the Canadian Research Institute for the Advancement of Women, immigrant women are less likely than nonimmigrant women to have paid employment, 
immigrants are well known: discriminatory workplaces, racist hiring practices, and the Canadian government's refusal to recognize foreign qualifications and degrees, coupled with, in some cases, limited fluency in English, all marginalize them in low wage and unstable employment sectors (Smith 2004; Martin and Mosher 1995). These structural barriers exacerbate their vulnerability and raise several questions about the benefits of zero tolerance approaches. If unprepared for the loss of their partners, immigrant women could lose critical financial support following mandated police and court intervention in their lives.

As stated earlier, arguments for mandatory charging rest on the characterization of police as protectors. However, with abused immigrant women, this assumption is questionable. For those victims who lack legal status entirely, the police offer few assurances of safety, given the likelihood of deportation (Martin and Mosher 1995). In cases where legal status is secure, turning to the criminal justice system is still fraught with complications. Immigrant victims contemplating police assistance often decide against it for fear of being cast as passive victims of tradition and invoking stereotypes. Since $9 / 11$, these concerns have become especially pronounced, particularly for abused Islamic women (Thorncliffe Neighbourhood Office 2006). As one woman in a Toronto-based study on woman abuse notes:

As a convert into the religion [Islam] ... nowadays, there is such a negative perception of the religion, men as abusers.... I didn't want to play the stereotype and go out into the community. On the one hand, here I am professing that I believe in the religion ... and on the other hand, I' $m$ talking about the same thing everyone else is talking about ... a [Muslim] man hitting a woman. (Thorncliffe Neighbourhood Office 2006)

Along with concerns about fuelling stereotypes, pressures to maintain the integrity of communities and families also lead to a distrust of police (Crenshaw 1991; Wachholz and Miedema 2000; Shirwadkar 2004; Admali et al. 2008). In communities that experience or had previously experienced racist encounters with the criminal justice system both in home and host countries, calling the police carries considerable stigma and risks to social capital. Many victims feel tremendous guilt for invoking the system and risk being ostracized from their communities

despite the fact that, on average, they have higher levels of education than Canadianborn women (Morris and Sinnott 2003). Immigrant women employed in full-time work also earn less than nonimmigrant employed full time. Statistics indicate that new immigrant women between the ages of 25-44 in full-time employment for one year earned $\$ 14,000$ less than Canadian-born women (Admali, Kim and Rupra 2008:13). 
if past experiences were unfavourable. ${ }^{15}$ Finally, fears of a racist police response also question the contention that mandated police intervention is always beneficial. Shirwadkar (2004) and Wachholz and Miedema (2000) both found that many immigrant women were reluctant to call the police in Canada "out of fear that an officer would use his or her authority to engage in physical force with either the victim or offender in woman abuse cases" (Wachholz and Miedema 2000: 309).

\section{The Promise of Community Intervention}

Aggressive criminal justice intervention clearly leaves immigrant victims in a bind. Abused immigrant women are far more likely to encounter detrimental legal, financial, and social consequences following mandated intervention than Canadian-born women. In recognition of these systemic failures, policy initiatives generally advocate increased community-based supports to either replace or buffer the impact of zero tolerance approaches. The most common recommendations are: ongoing education and information sessions about woman abuse in the community; the use of existing settlement and ESL services as venues for public education on the issue; increased linguistic and culturally appropriate outreach efforts; creative community-based initiatives that provide support and reduce isolation rather than severing relationships and "rescuing" victims; and ensuring that victims have the ability to make informed choices and understand the implications of calling the police (Wachholz and Miedema 2000; Menjivar and Salcido 2002; Shirwadkar 2004; Martin and Mosher 1995). Far less coercive than criminal justice intervention, community-based organizations are considered the most promising mechanism to ensure that immigrant victims have the requisite support to protect themselves from both their abusers and the criminal justice system.

Yet, what is actually known about this sector and the mediating role it performs between the criminal justice system and victims of abuse? In light of these recommendations, exploring in detail what happens at the intersections of the criminal justice system, community organizations, and immigrant communities is critical. Based on how we gener-

15. According to Rafiq: "The role of the police can be particularly threatening in some communities, especially those who come from countries where police are arresting, killing and torturing people. A woman will experience strong feelings of guilt and betrayal if she has to call the police in order to stop the violence. The community, again, is likely to play an important role in condemning the woman who called the police or went to court, if the man had been previously jailed or tortured in his country of origin. She, then, will be accused of using a repressive institution to inflict more pain on 'the poor man,' so to speak" (Rafiq 1991 as quoted in Admali, Kim, and Rupra 2008). 
ally imagine their work, to assume that agencies already perform the vast majority of recommended activities noted earlier is not misguided. The few available studies on immigrant violence against women services confirm this view. For instance, in her study of twelve organizations located throughout the United States, Merchant (2000) found that agencies offered a range of services, including counselling, legal assistance, translation, court accompaniment, immigration assistance, and advocacy (Merchant 2000:255: also see Rudrappa 2004:592) Agnew's (1998) comprehensive account of the emergence of ethno-specific violence against women services in Toronto reports similar findings. Finally, even a cursory glance at the service descriptions of most Torontobased community organizations illustrates the sector's provision of a variety of services, such as ESL and linguistic and culturally appropriate antiviolence outreach and counselling. ${ }^{16}$ Thus, in cities equipped with community-based, immigrant supports, the initiatives hailed as potential solutions appear to be standard practice. To more fully understand how community-based advocates support abused women, overcome community silence, and manage the potential consequences of mandated criminal justice intervention, we need to examine not only the services they offer, but the specific details of their interaction with victims and the communities they serve. ${ }^{17}$

\section{Methodology}

Toronto provides an excellent setting to examine the interactions between community-based service providers and the immigrant women who attend for support. Recent statistics indicate that immigrant populations from a variety of regions now comprise around 45.7 percent of the city's total population (Statistics Canada 2006). Not surprisingly, the network of nonprofit agencies serving immigrants is extensive. In an attempt to catch a glimpse into this sector, the following reports on interviews conducted with nine frontline staff and executive directors from eight community organizations in Toronto. The interview findings are supplemented with ethnographic observations of a day-long workshop devoted to improving existing community-based services to abused immigrant women. Over twenty service providers from various agencies throughout Toronto attended the seminar. The project is informed by a series of

16. See, for example, the service descriptions for organizations listed in 211Toronto.ca.

17. Although both Rudrappa (2004) and Agnew (1998) provide in-depth interviews with service providers working for immigrant women's organizations in the South Asian community, neither focus on how current criminal justice interventions affect their work or on how service providers overcome silence and stigma. 
informal interviews conducted with workshop participants throughout the day. My own professional experience working in the criminal justice system and with community organizations involved in the provision of woman abuse services also informs the analysis of my findings.

Gaining a sense of how current criminal justice policies and barriers to public discussions on violence against women affect the capacities of community organizations to support immigrant women is a central research objective. Accordingly, the following are some of the questions guiding this research: How does mandated criminal justice intervention affect the abilities of organizations to support abused immigrant women, particularly those with precarious legal status? Is it standard practice for agencies to relay information about these policies during public education initiatives? How do service providers overcome the complications associated with discussing woman abuse in public? If they are successful, what are their outreach efforts and what strategies do advocates employ to overcome the silence surrounding the issue?

The organizations selected for this project were found through 211Toronto.ca, an online directory of nonprofit and community-based organizations in Toronto. ${ }^{18}$ The 211 database categorizes agencies according to their specific services. Agencies listed under the headings "Counselling for Abused Women," "Settlement Services for Newcomers," "Culturally Specific Settlement Services," and "Legal Clinics" were reviewed. The list of agencies to contact was refined based on the scope of service provision - only settlement agencies that provided services for abused women, women's organizations that catered to immigrant populations, and legal clinics that provided services to abused immigrant women were consulted. Thus, although over a hundred Toronto-based immigrant agencies, ethno-specific women's organizations, and legal clinics currently advertise their services in 211 Toronto, approximately 25 organizations were deemed eligible based on the listings in the directory. Of the 25 organizations that were contacted, a total of 8 replied to requests for interviews and agreed to participate in this study. Of these 8,6 can be classified as ethno-specific or immigrant women's organizations and the other 2 as community legal clinics.

In-person and telephone interviews were conducted with seven executive directors and two direct service workers. While the initial goal was to interview a frontline worker in addition to a management staff at each agency, this was only possible with one of the agencies due to the un-

18. 211Toronto.ca is a comprehensive and up-to-date registry of community organizations and social services in Toronto. The information on the website was previously only available to service providers and frontline workers based in the voluntary sector to provide appropriate referrals for clients. The guide became open to the public in June of 2002. See 211Toronto.ca for further information. 
availability of the former during the time at which interviews were conducted. However, all the directors interviewed for the project reported that they frequently engage in direct service provision with immigrant victims in addition to their management responsibilities.

The majority of interviews for this study were conducted in the spring of 2006. Interviewees were asked both open and closed questions about their experiences working with immigrant communities, abused immigrant women, and criminal justice professionals. Participants were also questioned about their awareness of and thoughts about mandatory charging and aggressive prosecution policies. The findings of this study are based on summaries of their responses to the interview questions. Interview findings were supplemented with summaries of informal interviews conducted with services providers during a day long workshop in February of 2008. I asked workshop participants general questions about their experiences with and opinions about mandatory criminal justice intervention. These conversations were largely a continuation of the discussions initiated during workshop activities. Participants were informed of the subject of the study and asked to elaborate on the examples they provided during discussions of difficult or problematic cases. Finally, the exchanges between service providers and workshop facilitators were noted in their entirety and used to supplement both formal and informal interview findings. The facilitators outlined relevant criminal justice, immigration, family, and social welfare policies and provided a thorough review of the immigrant specific barriers that abused women confront when interacting with state and legal institutions. Service providers frequently contributed their insights and frontline experiences to the wider discussion, particularly in relation to overcoming systemic barriers, and navigating the web of child welfare, criminal justice, immigration, and social assistance bureaucracies.

\section{Organizational Profiles}

The eight agencies that participated in the study have been operating for about ten to fifteen years. Of the nine service providers that offered interviews, all but three had worked in their positions for approximately ten years. Apart from three organizations that delivered services to specific ethno-racial communities, most reported providing services in a number of languages to a variety of communities. The more general immigrant organizations provided services to a variety of populations, including the Croatian, Serbian, Somali, Latin American, South Asian, and Portuguese communities. All of the agencies in the sample stressed that they turned 
no one away. The majority of interviewees reported that on average, staff spoke between ten to fifteen languages, so only on rare occasions were language barriers an issue. If they were encountered, most either relied on family members or friends of the victim for assistance or on professional interpreters.

All the organizations reported similar mandates. While the two legal clinics in the sample advised that their primary role was to assist lowincome immigrants and refugees in navigating the immigration and criminal justice systems, the women's organizations stressed their commitment to the provision of culturally sensitive, multilingual counselling and support services to victims of woman abuse. The majority of interviewees advised that they worked from a feminist and antioppression framework and indicated that their organizations were established to address the barriers that differentiate the experiences of immigrants from those of the mainstream population.

\section{Creating "Home": Empowerment, Cultural Sensitivity, and Making Space SAFE}

The degree of interaction between community organizations and abused immigrant women is extensive. Service providers frequently develop ongoing relationships with women that can last anywhere from a few weeks to a year. All of the immigrant women's organizations interviewed for this study provide an array of services, including: court accompaniment, outreach and education on woman abuse, support with navigating social assistance and public housing bureaucracies, referrals to lawyers, help with filling out forms, group and individual counselling, as well as general assistance with a variety of settlement-related activities such as enrolling children in school, acquiring a social insurance number and English as a Second Language courses (ESL). The following account from a worker at an immigrant women's organization is typical of the services offered to victims upon ending abusive relationships:

Everything. Basically, they'll come and we'll assist them. A lot of it is financial, to help them get back on their feet. They need assistance for housing. Some of them may need a shelter allowance.... A lot of these women have never budgeted, so we bring them to the bank to open bank accounts and assist them with budgeting. The first visit, I always go with them to Ontario Works (OW) [provincial welfare system].... And then, after that, the worker tells them they have to pursue support, so they have to get legal aid. So it's ongoing - the contact with the woman can be up to four months. 
Both legal clinics in the study reported that their primary functions were to provide victims with very general legal advice as well as referrals to lawyers and other community agencies. The interviewees differed, however, in their approaches to their work. One legal advocate was very clear about the boundaries of service at her organization:

I don't get too much into the trauma - I just make the referral to a lawyer. Our thing is to make sure that the referral is made to the appropriate lawyer who will understand the issue and understand domestic violence and do justice to that.

In contrast, transgressing boundaries was the norm for the other legal advocate in the sample. When discussing his work, he advised that his clinic offers support groups, operates a shelter for abused women and their children, and provides accompaniment and translation during appointments with lawyers. Empowerment, through on-going counselling and support, is the organization's mandate. In accordance with this objective, the interviewee described his approach as "client focused":

Our focus is that you [the victim] are the owner of your experience.... We need to assist with a sense of empowerment and self-esteem. We have to provide them with a safe environment. We have houses where only women stay. We tell them, this is your house, your children will be with you, just be yourself. Then we say, I will support you, tell me what you want.... We don't send people to ESL classes just because they have to go. You have to consider where they are and whether they are ready for it first.

Just as important as the array of services offered is the manner in which they are framed. All of the interviewees in the sample mentioned the importance of cultural sensitivity when delivering services and frequently commented on the limitations of mainstream organizations and shelters. One executive director, whose agency works with an East Asian community, discussed the Western cultural assumptions underlying the practice of counselling and how her agency attempts to overcome them:

Counselling ... talking is not a traditional thing that people [in this community] do. So the idea of coming in weekly to talk is very foreign to them [abused immigrant women]. I know that there are some [mainstream] organizations out there that are ... not strict ... but they do have guidelines where if you miss three counselling sessions, your case is closed. But with us, we do understand that it's really new to them or it's very strange for them to come and talk to a stranger.

For many service providers, cultural sensitivity and creating a welcoming, home-like environment go hand in hand. Interviewees tend to code 
"whiteness" and "the mainstream" as formal and hierarchical; in opposition to this, they strive for informality as a mechanism to ensure that women feel comfortable speaking about their experiences.

Employing language and practices that disrupt the hierarchy between the client and service provider, such as having an open door policy or invoking sentiments of kinship are common. The same executive director notes:

I find that the clients - they don't treat us like clinicians, or case managers or workers. They treat us more like friends. In Vietnamese, when you address one another, you call them "big sister," "big brother," "little sister," "little brother."... The terms "you" and "me" are very strong, very overly polite. They use familiar terms. They come in and we just try to make them feel like they're at home. We try to encourage them to develop that relationship. For example, they'll come in and they see our receptionist and they talk and they even come right to the back and into my office. In some organizations, you can't really do that.

Creating safe shelter space in private homes rather than in public institutions is another illustration of the culturally sensitive, "homing" technique immigrant and ethno-specific organizations employ. One executive director of a Tamil women's organization discussed the discomfort and alienation many women experience when they attend mainstream shelters. ${ }^{19}$ In recognition of these issues, her organization operates an underground, volunteer-run shelter service for victims who want to leave their partners, but do not want to attend "mainstream" shelters. The program relies on members of the Tamil community, who volunteer their homes indefinitely. Ensuring that women "blend into the community" and are given protection "without getting the system involved" are the primary goals of the program.

\section{Raising Legal Consciousness}

Community organizations play a central role in transmitting knowledge about a variety of legal, bureaucratic, and state processes. As mediators between state systems and civic society, community-based advocates are key in raising consciousness about a variety of issues, such as how the police and courts respond to incidents of woman abuse, the impact

19. Agnew (1998) has written extensively about the differing service delivery priorities of mainstream and ethno-specific shelters and problems that immigrant victims encounter when accessing shelter services that operate from a monocultural and monolingual framework. Crenshaw (1991) provides a similar account of mainstream shelters in New York City. 
of charging on immigration status and the availability of specific housing and welfare provisions reserved for abused women. Despite their invaluable role in raising legal consciousness, detailed accounts of their advocacy work are generally lacking, as is a sense of how organizations acquire their knowledge of various legal and state systems.

When prompted to discuss the specifics of the legal information they provide to victims, all of the interviewees said that their conversations tend to be very general and limited to explanations of legal terms and documents. One worker reported that the provision of "legal advice" actually entails explaining concepts such as "custody" and "probation." A related and integral aspect of community-based consciousness raising activities is systemic advocacy. An executive director of a legal clinic remarked that a key element of his work entails "getting the legal system to understand and consider migrant realities." To ensure an appropriate response, he insists on accompanying victims to meetings with lawyers and alerting them to "other parts of the law" when they offer women advice. Other common advocacy activities include making phone calls, internet research, and providing linguistic translation.

Service providers thus differentiate their work from that of lawyers, stressing that they do not have the appropriate credentials to act in lieu of legal professionals. ${ }^{20}$ Despite lacking Canadian credentials, interviewees exhibited vast knowledge of the administrative rules of various systems, including the criminal justice system, social assistance, and immigration. Though technically not formal legal knowledge, their working knowledge is just as crucial to ensuring women obtain adequate services and are aware of their rights.

When asked how they acquire their legal and systemic knowledge, all of the organizations reported close working relationships with either the criminal justice system or family and immigration lawyers. Five of the immigrant women's organizations worked with various sectors of the criminal justice system, such as the Victim Witness Assistance Program, the police and crown attorneys either on an ad hoc basis or more regularly through intersectoral coalitions and committees. Training workshops and websites were also mentioned as important mechanisms for obtaining accurate and up-to-date information on administrative practices and criminal justice policies. One service provider reported that she

20. Though none of the interviewees were accredited to practice law in Canada, two of the participants in the study, both of whom worked for legal clinics, had backgrounds in the legal field. One had obtained an L.L.M. in Canada and another was a human rights lawyer in his home country. 
regularly attends training programs offered by Citizenship and Immigration Canada and the Attorney General's office. ${ }^{21}$

Finally, all of the immigrant women's organizations in the sample cite community legal clinics as invaluable sources of information on legal processes. Legal clinics provide assistance as needed, as well as through training sessions for frontline workers at their organizations.

In contrast, both interviewees working for the legal clinics in the sample reported virtually no interaction with police and crown attorneys for the purposes of information exchange, or for either acquiring or providing training. One executive director lamented that he has tried repeatedly to initiate ongoing training with the police, crown attorneys and the Ministry of the Attorney General, but that he has so far been unsuccessful. Both advised, however, that they frequently consulted with immigration, family, and defence lawyers on staff or closely affiliated to the agency for information.

\section{In Between Silence and SPEech}

As expected, the services and support community based workers offer to women fleeing abuse is extensive. Yet, how do abused immigrant women come to know about their services, particularly when most consider silence less risky than disclosing? Interestingly, when asked how women come to hear about the services they offer, all of the interviewees reported that women find their agencies through word of mouth. As one co-director notes:

The [other source of referrals] we have is our former clients. They are in the community. They know people in a situation who are in need of our services. Former clients, they bring a lot of people, word of mouth. We don't advertise. We don't even need to be in 211. We have at least fifteen intakes a week.

Findings indicating the importance of word of mouth in generating referrals are significant and worth exploring, considering the narratives of community silence often reproduced in the violence against women literature. Some studies on woman abuse in immigrant communities give the impression that immigrant women on the whole do not speak at all about the violence in their lives, since woman abuse is a "taboo subject" (see, for example, Menjivar and Salcido 2002). The taboo narrative, which casts silence as a cultural practice, should be differentiated from

21. This provision of training is most likely due to the fact that both provide funding for the organization. 
those that trace it to structural and material factors, such as concerns about invoking racist stereotypes; fears of negative immigration consequences; and a lack of trust of police, authority figures, or strangers more generally (see, for example, Crenshaw 1991).

Neither group of studies, however, sheds much light on whether barriers prevent immigrant women from speaking to each other. Research that implies women are too bound by tradition to speak about abuse may inadvertently validate the stereotype of immigrant victims as silent and helpless bystanders in their own oppression. Findings suggesting the importance of word of mouth in drawing referrals provide nuance and insight into existing claims and challenge interpretations of the silent immigrant victim. They imply that women speak to each other about the violence in their lives, or at the very least, about the difficulties they experience in their intimate relationships.

The ways in which immigrant women present themselves to frontline workers when attending for services, however, corroborate existing studies suggesting victims generally do not disclose violence when interacting with individuals unknown to them. The majority of service providers report that when victims attend their organizations for assistance, they prefer not to mention violence at the outset. Even more rare are occasions where women contact agencies when they are in crisis or in need of immediate intervention. Rather, women often attend organizations requesting settlement assistance or general advice. As one executive director explained:

They come, most of the times, because they know someone in the community. They don't come because they identify themselves as victims. They usually come for other needs that they have. Sometimes, they come in because they have some concerns about their children and parenting. Through that intervention, we then find that there are issues relating to abuse. The majority of women we see, it's a very small percent that come and say we are in an abusive situation.... They are very different from the people who have been here a while, because they already identify. The population that we work with, it's a new concept for them. It's something different. They haven't been recognized in their home countries.

A director of a legal clinic noted similar experiences:

Most of the time, women do not phone us and say I am in this [abusive] situation. Usually, she would have already been here for another reason. It's very rare that someone just phones when in a crisis.

Thus, from the perspectives of service providers, immigrant women appear to be relatively silent and generally lacking consciousness of their 
oppression as victims of male violence. However, findings that word of mouth eventually lead women to their services suggests that immigrant victims might in fact realize they are in abusive situations, and do speak to others about the difficulties in their lives and relationships.

Along with word of mouth, service providers advised that other community organizations were another significant source of referrals. One legal clinic noted that her organization receives close to $70 \%$ of her woman abuse referrals through immigrant women's agencies and service providers in housing and welfare. Contact with immigrant victims is also secured through public education and advertising in local newspapers and 211 Toronto. Finally, for those organizations that maintain relationships with various state institutions and criminal justice sectors, sources such as Children's Aid, the police, victim services, and other social service organizations provide a significant number of referrals.

\section{Advising Victims in Light of Mandatory Charging: To Call or NOT to CALL?}

Current criminal justice practices fail many victims, particularly those who are marginalized along the lines of citizenship, race, and class. The studies reviewed earlier illustrate the vulnerability of immigrant women following the mandated removal of abusive partners from households and raise several questions about the support community-based workers can realistically provide to victims experiencing both intimate and systemic violence. What interventions do service providers implement to support women experiencing violence at the hands of their abusers and the state? Do zero tolerance policies help or hinder their work? Since the police and other criminal justice professionals have done virtually nothing to raise awareness about the consequences of mandated criminal justice intervention, as mediators, community organizations may be the only hope in ensuring that abused women have the capacity to make informed decisions about invoking police assistance. By notifying victims and communities about criminal justice policies, they could potentially buffer the negative impact of systemic violence in their lives.

When asked whether they advise victims of mandatory charging, all of the service providers indicated that they always inform women of the consequences of calling the police. However, it was not entirely clear whether one of the interviewees in the sample understood the prosecution process and the implications of zero tolerance approaches. When asked whether victims already know about mandatory criminal justice intervention prior to attending agencies for assistance, all but the afore- 
mentioned organization noted that victims were completely unaware. Overall, service providers indicated that they do not encourage victims to phone the police unless they are in immediate danger. They operate according to feminist principles of empowerment and support women's own choices about how to best deal with the abuse in their lives. As one service provider notes, it is when victims are contemplating police intervention that they "really work with them" and "go with whatever they decide." Another executive director of a legal clinic reported similar strategies of intervention: "The client is the centre of all our activity. She is the owner of her reality. She decides what to do and provides all the information." The majority of the interviewees remarked that once they are aware of mandatory charging, most women decide never to phone the police. This resistance often becomes a cause for concern for service providers if victims are in high-risk situations and there are fears that severe injury or death may occur if police do not intervene.

Instances in which victims do not have secure legal status also pose a dilemma for service providers. According to the majority of interviewees, these cases are rare. However, two organizations reported that they frequently encounter situations involving victims who are either dependent on their partners for residency through sponsorship arrangements or without status entirely. When this occurs, mandatory charge policies place service providers in a considerable bind. Even if victims in these circumstances are in immediate danger, service providers are extremely reluctant to invoke police assistance, choosing instead to intervene independently. One director of a legal clinic advises:

[Immigration] status becomes more of an issue than protection. That's why we suggest that if you don't have a choice, call 911. However, if you have a choice, call us and we will deal with the situation. We don't want women to be alone. Sometimes we have situations of abuse where the women have been deported later on because they didn't have status. In order to avoid that, we have to deal with women ourselves. If you don't do it, they'll end up in detention. She was beaten and abused and now she ends up in detention. This is crazy. The justice system isn't sensitive to this.

Apart from informing nonstatus victims of the consequences of calling the police, making them feel less isolated, and ensuring that they are linked to appropriate legal supports - all of which are crucial to enhancing victim safety - service providers report that they are generally at a loss for what to do when assisting women with precarious status. In relation to those victims whose abusers are also their sponsors, one interviewee mentioned the possibility of initiating an immigration ap- 
plication under Humanitarian and Compassionate grounds. However, he advised that this process was far from ideal, since securing status on these grounds could take close to two and a half years. Another front line worker expressed frustration that she "really couldn't do anything" besides phone immigration and ask them to consider the occurrence of abuse in the relationship. Frustrated, she remarked:

Most of the time, it's easier for [the victim] to reconcile because immigration doesn't really care. They don't speed up the process, they don't do anything special for them, so in the long run, not only are they abused by their husbands, they're abused by the legal system as well.

Another service provider expressed similar sentiments: In her experience, "women would rather stay with an abusive man than confront an abusive system." The leverage that abusive sponsors exercise over victims, which is largely a product of Immigration Canada's sponsorship policies and categories of exclusion, is a significant concern from the perspectives of service providers. ${ }^{22}$ One frontline worker for an immigrant women's organization relayed a story about a former client who was being investigated by Immigration Canada. Shortly after the victim left her abusive relationship, her ex-partner complained to Immigration Canada, alleging that she had only married him for legal status. Immigration Canada proceeded to investigate the complaint and "made her life hell for about a year." All the service providers agreed that long-term systemic changes are required in both the criminal justice and immigration systems in order for victims with precarious status to secure proper protection and assistance. As one codirector of a legal clinic noted, "Protection should be the main issue, the main message. That will create better outreach for the victim than the mandatory charge policy."23

Cases in which victims phoned agencies for support to deal with the aftermath of mandatory charging are just as difficult. The majority of service providers remarked that women's lives are turned upside down following the sudden and unprepared loss of their partners, who could be removed from the household for a month or even up to a year, depending on whether the matter is dealt with via guilty plea or trial. Victims in these situations frequently phone agencies requesting help to get charges

22. For a more extensive discussion of categories of exclusion that prevent abused immigrant women from accessing social assistance and other services, see Mosher (2005).

23. This participant advocated the implementation of a "Don't Ask, Don't Tell" policy, which would direct the police to refrain from inquiring about immigration status when investigating cases of woman abuse. Currently, the campaign for the policy in Toronto, which extends to all municipal services, would prohibit inquiries into immigration status and prevent the release of immigration related information to Citizenship and Immigration Canada. 
dropped. One service provider at an immigrant women's organization noted:

I guess one of the biggest challenges is when women make the decision [to call the police] because they really feel they didn't have any other option, but they really were not prepared to do it. That is a problem for them and for us, because once they do not feel safe in the situation, they do not want to proceed. They refuse to go make a statement.... We have many women tell us they have to go to court and we're working with them and they agree to go, and then at the last minute, they decide not to go.

Considering these consequences, when asked about whether they believed mandatory charge policies helped or harmed immigrant victims, virtually all of the interviewees noted that while they can be helpful to those who have status and the appropriate supports to end their relationships, for most immigrant victims, systemic intervention makes their lives far worse:

It [the mandatory charge policy] harms them, because they lose their incomes, they lose their jobs, the guys can't come home, they have to pay twice the amount of rent. Everything is costing them more. And all they want is a warning. I would say that more than half of the cases are of this type. More than half just want someone else to tell them [their partners], "This is not on. You can't hit me, you can't do this," but straight away, they charge.... A lot of people want to get back together... They say, "Can he come and see me because I can't pay the mortgage, I can't pay the car, I don't know where the car insurance is, I can't take the kids to school." So it gets very hard for them.

Another frontline worker at a legal clinic made similar remarks based on her experiences:
Most of the time, the women are not sure of how this [the mandatory charge policy] works or what happens. And then they see their lives crumbling and they haven't made changes in their lives. They've come to Canada, haven't learned English, they have no family and friends, no infrastructure and are completely isolated, have a few children, and don't know how to deal with them. For them it's very traumatic and extremely isolating.

Thus, the observations of service providers corroborate existing research on the impact of aggressive state intervention on immigrant women. Interviewees note that women are completely unaware of mandatory charging and generally refuse to phone the police once informed of the policy. The few women who already know about the policy are 
only aware of it after having phoned the police, and are accessing support from agencies to deal with the aftermath of arrest. Although such cases are rare, when victims with precarious status are caught within the grips of the criminal justice and immigration systems, the majority of service providers say that women generally feel revictimized, rather than helped by the law. Immigrant victims are often unprepared for the sudden removal of partners, which results in their increased isolation and financial hardship. These detrimental consequences can be mitigated if victims consult organizations prior to phoning the police. Committed to feminist principles of empowerment, service providers always ensure victims are aware that they will not be able to withdraw charges if they access the system. However, managing cases and ensuring victim safety can be extremely difficult if women are at high risk of injury or death and still refuse to call the police.

\section{“Using Fronts": Outreach Strategies and Immigrant Communities}

Though immigrant community organizations routinely engage in educative efforts to raise awareness about woman abuse, very little is known about the content of these initiatives or about the strategies service providers use to overcome barriers to discussions of violence. Nonetheless, public education and outreach are consistently cited as essential means to ensure the safety of abused immigrant women (Wachholz and Miedema 2000; Menjivar and Salcido 2002). Outreach may also be the most effective way to inform immigrant women and their wider communities about the consequences of mandatory criminal justice policies.

Outreach, for the purpose of this study, refers to recruitment activities as well as public education efforts for existing clientele and immigrant communities more generally around woman abuse and the law. When asked whether their organizations engage in outreach, all of the immigrant women's agencies, apart from one, reported involvement in an array of activities, including: the distribution of fliers in supermarkets, ESL classes, churches, apartment buildings, shopping malls and laundrettes; advertising in ethno-specific newspapers; and appearances on ethno-specific television and radio programs. A few noted that they perform door-to-door intervention and speak to women directly in their homes. Many also organize information sessions with immigrant women who have already attended their organizations for services, but may not have identified themselves as victims of abuse to the organization. Both of the legal clinics in the study also report involvement in outreach, yet advised that the majority of their efforts were geared towards training 
frontline workers in mainstream community agencies on immigration and refugee issues.

Service providers elaborated on the difficulties they encounter when conducting outreach on woman abuse and the law. They cite the potential of alienating immigrant communities as a central concern. One interviewee commented that her agency never lists the phrase "domestic violence" on flyers, because "no one wants to hear about domestic violence." Instead, flyers advertise the availability of services, such as support groups and legal advocacy. Another interviewee at the same agency corroborated this account, reporting that their brochures note the availability of "settlement information," rather than woman abuse services. Only one of the interviewees in the study indicated that her organization does not perform outreach for the purpose of recruiting clients. She prefers instead to "keep a low profile to ensure the safety of her workers." 24

A few service providers mentioned that they often "use fronts" and other creative strategies to overcome barriers to discussions of woman abuse. For example, one frontline worker described her involvement in the production of five-minute skits on violence against women aimed at the South Asian community. The short plays highlighted the various forms of abuse in relationships and were geared towards helping women name the violence in their lives. Another service provider mentioned that her organization tries to mask the topic of women abuse by couching the issue in less controversial terms, such as "relationship skills." Her organization's Digital Story Project aims to encourage discussion about abusive and healthy relationships by helping women write narratives of their own relationships. Similarly, another service provider advised that her organization's woman abuse outreach strategies are "called many different names." The "Sewing Project" is an example of a recent initiative that purports to focus exclusively on economic skills, but includes consciousness-raising activities on violence against women.

Despite some of these success stories, overall, most agencies find that engaging in public education, particularly to the wider community, is generally a struggle. For example, service providers report that they have tried repeatedly to hold information sessions on woman abuse in existing public venues, such as churches or ESL classes, but that those running the institutions or events are rarely on side:

Violence prevention is a very touchy issue. No one likes to talk about that. And even when you do approach them, they really are very reluctant to do any kind of activities because they really feel that it's going to alienate

24. This service provider noted that a number of men in the ethno-racial community that her organization serves were opposed to her work. After receiving anonymous threats, she ceased her outreach activity. 
people that are coming to them or stop people from coming to them. So you have to be very careful about how you say these things.

Another service provider relayed a similar story. Although her organization consistently provides information sessions on family and immigration law in ESL classes, her attempts to offer any in relation to woman abuse have so far been unsuccessful. She stated that ESL instructors and program managers sometimes fear that public discussions around violence would do more harm than good..$^{25}$

Finally, though a few organizations did report some success with outreach and public education, information on the criminal justice system rarely makes the agenda. Service providers explained that their outreach initiatives are generally geared towards consciousness raising, rather than providing in-depth discussions on the legal implications of calling the police. Encouraging women to recognize abuse and speak about their experiences are usually the primary goals of outreach. When asked to describe their information sessions, one service provider noted:

I don't think we really talk so much about the legal terminology or anything like that. We just say, "in Canada, this is against the law and this can be a criminal offence." [We review] the different types of abuse and what can be perceived as an offence, pushing and all sorts of things.

It appears that any discussion of woman abuse and the criminal justice system tends to be very general: immigrant women are told that violence against women is against the law in Canada and that they could call the police if they are afraid or in crisis. Explanations of the differences between criminal, family, and immigration law also appear to be standard practice, but these discussions also tend to lack specific detail and primarily direct women to the appropriate legal system depending on their needs. Even more problematic than this lack of information in light of the impact of aggressive criminal justice strategies, however, is the tendency to idealize the Canadian legal system and its response to woman abuse. While this was not common amongst all the organizations in this study, one service provider did report that her general message to South Asian women during public outreach is that they are "free" in Canada and that the law is on their side. There was little recognition of the need

25. It is not entirely clear who these ESL instructors are, as most of the interviewees spoke very generally about the barriers that they had experienced. Virtually all of the immigrant women's organizations in this sample offer ESL courses, so it is entirely possible that the instructors mentioned are affiliated with the agencies sampled in the study. However, these classes are also standard for a number of immigrant settlement organizations throughout Toronto. In addition, service providers did not elaborate on the rationale of those expressing concern about violence against women outreach initiatives. 
to discuss mandatory charging and the repercussions of calling the police. Concerns that employing such tactics may inadvertently encourage women to call the police for assistance were also not considered.

Thus, although outreach is repeatedly cited as the most effective means of ensuring that immigrant women know their rights and the repercussions of invoking the criminal justice system, in practice, it may not be as effective as anticipated. First, the difficulties and discomfort around openly acknowledging woman abuse deprive many agencies of the capacity to engage in any public education on violence against women. Second, when service providers actually manage to overcome barriers and hold public discussions on woman abuse, these initiatives are generally confined to helping women name and identify the violence in their lives. Rarely do they address existing criminal justice policies on woman abuse. Although consciousness raising is undoubtedly an invaluable service, the lack of attention to the intricacies of police and court intervention does not provide women with the knowledge required to make informed decisions about calling the police.

Despite these rather discouraging findings, virtually all of the service providers recognized the importance of outreach to ensure the transparency of current criminal justice practices. Close to half of the interviewees lamented the fact that very few immigrant women are aware that they are unable to drop charges following police intervention. One interviewee remarked that increasing awareness of mandatory charging is critical to alleviating the vulnerability of nonstatus and sponsored victims. Of particular concern to her was the failure of the system to make its own policies known: "The criminal justice system doesn't inform people of the laws and their rights. We hear about nutrition and health, but not about woman abuse." Another worker at a community legal clinic expressed considerable frustration about the lack of interest in outreach amongst key settlement institutions in immigrant communities, despite her organization's willingness to provide public education on criminal justice policies:

A lot of people don't know about the mandatory charge policy. They just don't. And that's my thing. Why can't we educate immigrant women in LINC [ESL] classes, which are already funded by the government? I'm not saying we need to develop more resources. Just use existing resources to teach them what mandatory charging is, when to call 911 , and what child protection is. 


\section{Conclusion}

Shifting the responsibility of victim protection from the criminal justice system to the community is repeatedly cited as the solution to the difficulties immigrant victims confront following mandated police and court intervention. Accessing community supports, however, may not be so straightforward either. Little is known about how immigrant victims find their way to community agencies, and the specifics of service providers' interactions with women and the communities they serve. Before assessing whether decentring the criminal justice system is the answer, we need more knowledge of the activities of community organizations, particularly the services they provide, how their work is affected by current criminal justice practices, how they address and overcome barriers to public discussions of woman abuse, and what they tell victims and immigrants about the criminal justice system.

The findings of this study on community organizations in Toronto, Ontario illustrate the critical role of the voluntary sector in supporting abused immigrant women. They also highlight the difficulties organizations confront when raising consciousness on woman abuse and the law, and the creative and culturally sensitive strategies they employ to circumvent these barriers. Although, theoretically, community-based organizations, as mediators, are in a prime position to raise awareness around woman abuse and the law, in practice, public outreach and education is not so easy. Community silence is a significant barrier. About half of the service providers interviewed have been unsuccessful in their attempts to negotiate access to existing community forums in which public education would be most beneficial. For those who report some success, discussions of mandatory charging and prosecution rarely make the agenda. Nonetheless, agencies provide an array of essential services to abused immigrant women, including: links to lawyers, general legal information and help with navigating various systems, such as immigration, criminal justice, child welfare, and social assistance. Additionally, they perform a crucial role in providing support and advocacy to abused women in the wake of criminal justice intervention.

Service providers' experiences with mandatory charging illustrate that not only do these policies make the lives of abused immigrant women more difficult; they also place organizations in a considerable bind when engaging in advocacy for victims. Virtually all the interviewees noted that once informed of the policy, women rarely consider invoking police protection. If victims are in high-risk situations and shelter services are not available, service providers are often at a loss to protect them. Just as difficult are those cases involving abused women with precarious im- 
migration status. In these instances, the police and courts do not offer a viable means of protection. For victims who phoned the police unaware of mandatory charging, advocates can do little to prevent deportation or other negative immigration consequences.

Community organizations do considerable work to protect immigrant victims of violence from both their abusers and aggressive criminal justice interventions. However, as long as zero tolerance approaches remain unchanged, immigrant women are unlikely to receive the support they require to end, or cope with the violence in their lives. In the meantime, community-based advocates have developed short-term strategies to avoid relying on the police and courts. Increasing the capacity of immigrant communities to take ownership of woman abuse, they argue, could be one way to buffer the negative impacts of systemic involvement. Implementing leadership development programs, engaging local faith leaders, and public shaming/naming rituals are just a few examples of community accountability strategies that have been employed throughout Canada and the rest of North America (Adamali, Kim, and Rupra 2008). These initiatives take important first steps in holding abusers accountable, supporting victim safety and shifting the responsibility of woman abuse from the system to the community. Ultimately, however, the reform of mandatory charging and prosecution is essential to ensure immigrant women find the support they need.

\section{REFERENCES}

Adamali, Andalee, Janet Kim, and Angie Rupra. 2008. Family Violence against Immigrant and Refugee Women: Community Development Strategies. Ontario Council of Agencies Servicing Immigrants (OCASI).

Agnew, Vijay. 1998. In Search of a Safe Place: Abused Women and Culturally Sensitive Services. Toronto: University of Toronto Press.

Crenshaw, Kimberle. 1991. Mapping the margins: Intersectionality, identity politics, and violence against women of color. Stanford Law Review 43(6):1241-1299.

Department of Justice Canada. 2005. Final report of the ad-hoc federal-provincial-territorial working group reviewing spousal abuse policies and legislation. 1-105. Available at: http://www.justice.gc.ca/eng/pi/fv-vf/rep-rap/ spo_e-con_a.pdf Accessed October 13, 2009.

Hanna, Cheryl. 1996. No right to choose: Mandated victim participation in domestic violence prosecutions. Harvard Law Review 109(8):1850-1910.

Hilton, N. Zoe. 1988. One in ten: The struggle and disempowerment of the battered women's movement. Canadian Journal of Family and the Law 7:313-335. 
Jiwani, Yasmin. 2006. Discourses of Denial: Mediations of Race, Gender and Violence. Vancouver: University of British Columbia Press.

MacLeod, Linda. 1980. Wife Battering in Canada: The Vicious Circle. Ottawa: The Canadian Advisory Council on the Status of Women.

MacLeod, Linda and M.Y. Shin. 1990. Isolated, Afraid and Forgotten: The Service Delivery Needs and Realities of Immigrant and Refugee Women who are Battered. Ottawa: National Clearinghouse on Family Violence, Health and Welfare Canada.

Martin, Dianne L. and Janet Mosher. 1995. Unkept promises: Experiences of immigrant women with the neo criminalization of wife abuse. Canadian Journal of Women and the Law 8:3-44.

Martin, Dianne L. 1998. Retribution revisted: A reconsideration of feminist criminal law reform strategies. Osgoode Hall Law Journal 36(1):151-188.

Menjivar, Cecilia and Olivia Salcido. 2002. Immigrant women and domestic violence: Common experiences in different countries. Gender and Society 16(6):898-920.

Merchant, Munira. 2000. A comparative study of agencies assisting domestic violence victims: Does the South Asian community have special needs? Journal of Social Distress and the Homeless 9(3):249-259.

Mills, Linda. 2003. Insult to Injury: Rethinking our Responses to Intimate Abuse. Princeton, NJ: Princeton University Press.

Ministry of the Attorney General. 2004. British Columbia policy on the criminal justice response to violence against women and children. Victoria: Ministry of the Attorney General.

Ministry of the Solicitor General. 2000. Policing Standards Manual. Toronto: Ontario Ministry of the Solicitor General.

Morris, M. and J. Sinnott. 2003. Fact sheet, immigrant and refugee women, Canadian Research Institute for the Advancement of Women. www.criawicref.ca/indexFrame e.htm Accessed October 12, 2009.

Morrow, Marina, Olena Hankivsky and Colleen Varcoe. 2004. Women and violence: The effects of dismantling the welfare state. Critical Social Policy 24(3):358-384.

Mosher, Janet. 2005. The complicity of the public state in the intimate abuse of immigrant women. Unpublished paper, under review.

Pierson, Ruth Roach. 1993. The politics of the body. Pp. 98-122 in Pierson et al., eds., Canadian Women's Issues. Volume 1, Strong Voices. Toronto: James Lorimer and Company.

Rafiq, F. 1991. Towards Equal Access: A Handbook for Service Providers Working with Immigrant Women Survivors of Wife Assault. Ottawa: Immigrant and Visible Minority Women Against Abuse. 
Razack, Sherene. 1998. Looking White People in the Eye: Gender, Race and Culture in Courtrooms and Classrooms. Toronto: University of Toronto Press.

Rudrappa, Sharmila. 2004. Radical caring in an ethnic shelter: South Asian American women workers at Apna Ghar, Chicago. Gender and Society 18(5):588-609.

Shirwadkar, Swati. 2004. Canadian domestic violence policy and Indian immigrant women. Violence Against Women 10(8):860-879.

Smart, Carol. 1989. Feminism and the Power of Law. New York: Routledge.

Smith, Ekuwa. 2004. Nowhere to turn? Responding to partner violence against immigrant and visible minority women. Ottawa: Canadian Council of Social Development.

Snider, Laureen. 1994. Feminism, punishment and the potential of empowerment. Canadian Journal of Law and Society 9(1):75-104.

Stark, Evan. 2005. Reconsidering state intervention in domestic violence cases. Social Policy and Society 5(1):149-159.

Statistics Canada. 2006. Immigration in Canada: A portrait of the foreign-born population, 2006 census: Portraits of major metropolitan centres. Ottawa: Statistics Canada.

Thorncliffe Neighbourhood Office. 2006. Thorncliffe Crime Victims Support Initiative: Report on the Findings from Focus Groups and Personal Interviews on Family Violence and Hate Crimes. Toronto: Ministry of the Attorney General of Ontario.

Wachholz, Sandra and Baukje Miedema. 2000. Risk, fear, harm: Immigrant women's perceptions of the 'policing solution' to woman abuse. Crime, Law and Social Change 34:301-317.

Wanless, Marion. 1996. Mandatory arrest: A step towards eradicating domestic violence, but is it enough? University of Illinois Law Review 533-586.

Rashmee Singh is a PhD Candidate at the Centre of Criminology, University of Toronto and a Doctoral Fellow at the American Bar Foundation. Her dissertation research explores immigrant community organizations involved in the provision of violence against women services in Toronto and the mediating work they perform between the criminal justice system and immigrant communities. Her theoretical and academic interests include violence against women, postcolonial feminism, immigration, and legal consciousness.

rashmee.singh@utoronto.ca 